\title{
HUBUNGAN KARAKTERISTIK, TINGKAT PENGETAHUAN DAN SIKAP IBU DENGAN PEMILIHAN ALAT KONTRASEPSI PADA PASANGAN USIA SUBUR DI KECAMATAN SIDEMEN KABUPATEN KARANGASEM BALI
}

\author{
Ni Putu Ditadiliyana Putri ${ }^{1}$, Dyah Pradnyaparamitha D. ${ }^{2}$, Luh Seri Ani ${ }^{2}$ \\ ${ }^{1}$ Program Studi Pendidikan Dokter Fakultas Kedokteran Universitas Udayana \\ ${ }^{2}$ Program Magister Ilmu Kesehatan Masyarakat Fakutas Kedokteran Universitas Udayana \\ *Email: diliana.putri07@gmail.com
}

\begin{abstract}
ABSTRAK
Program keluarga berencana memungkinkan pemerintah untuk menurunkan angka fertilitas dan meningkatkan perbaikan kesehatan, kesejahteraan, hak asasi manusia, dan pendidikan. Akan tetapi dibeberapa negara berkembang penggunaan kontrasepsi masih terbatas. Penelitian tentang faktor yang berhubungan dengan pemilihan penggunaan alat kontrasepsi sudah banyak dilakukan tetapi hasilnya masih tidak konsisten. Penelitian ini ditujukan untuk mengetahui hubungan karakterisktik, tingkat pengetahuan, dan sikap ibu terhadap pemilihan alat kontrasepsi. Studi cross sectional dilakukan terhadap 91 wanita usia subur yang dipilih dengan metode simple random sampling. Penelitian ini dilakukan pada bulan Maret hingga April 2018 di Kecamatan Sidemen Kabupaten Karangasem Bali. Data dikumpulkan dengan metode wawancara di rumah masing-masing responden. Data yang dikumpulkan adalah tentang pemilihan alat kontrasepsi, karakteristik, tingkat pengetahuan, dan sikap. Data hasil penelitian dianalisis dengan Chi Square untuk mengetahui faktor yang berhubungan dengan pemilihan alat kontrasepsi. Hasil penelitian menunjukkan bahwa satu-satunya faktor yang berhubungan dengan pemilihan alat kontrasepsi adalah tingkat pengetahuan ibu $\left(X^{2}=0,163, P=0,01\right)$. Dapat disimpulkan bahwa pengetahuan ibu berhubungan dengan pemilihan alat kontrasepsi pada PUS.
\end{abstract}

Kata Kunci:tingkat pengetahuan, persepsi, pasangan usia subur, metode kontrasepsi, pemilihan alat kontrasepsi.

\begin{abstract}
Family planning program allows the government to reduce fertility rates and improve health, welfare, human rights and education improvements. However, in some developing countries contraceptive use is still limited. Research on factors related to the selection of contraceptive use has been widely carried out but the results are still inconsistent. This study aims to determine the relationship between the characteristics, level of knowledge, and maternal attitudes towards the selection of contraceptives. A cross sectional study was carried out on 91 women of childbearing age who were selected by simple random sampling method. This research was conducted in March to April 2018 in Sidemen Subdistrict, Karangasem Regency, Bali. Data was collected by interview method in each respondent's house. The data collected is about the selection of contraceptives, characteristics, level of knowledge, and attitude. The results of the study were analyzed by Chi Square to determine the factors associated with the selection of contraceptives. The results showed that the only factor related to the selection of contraceptives was the level of maternal knowledge $(\mathrm{X} 2=0.163, \mathrm{P}=0.01)$. It can be concluded that maternal knowledge is related to the selection of contraceptives. So it needs to be socialized about the advantages and disadvantages of each contraceptive method to ensure the right choice of contraception for mothers of childbearing age.
\end{abstract}

Keywords: level of knowledge, perception, couples of childbearing age, contraceptive methods, selection of contraceptives.

https://ojs.unud.ac.id/index.php/eum $\mathbf{4 0}$ 


\section{PENDAHULUAN}

Sebanyak 214 juta wanita usia subur dinegara berkembang tidak menginginkan kehamilan tapi tidak menggunakan alat kontrasepsi. Beberapa metode kontrasepsi seperti kondom, membantu untuk mencegah penularan penyakit infeksi HIV dan penyakit menular seksual lainnya. ${ }^{1}$ Di Asia, tingkat penggunaan kontrasepsi tertinggi ditemukan di wilayah Timur dan Tenggara Asia. Di beberapa negara yang ada di Asia, penggunaan kontrasepsi pada tahun $2015>70 \%$, dengan perkiraan tertinggi sebesar $83 \%$ di temukan di Negara Cina dan terendah ditemukan di Afghanistan dan Timor-Leste yaitu sebesar $29 \%$. $^{2}$ Penggunaan alat kontrasepsi bertujuan untuk mengatur jarak kehamilan dan untuk menunda kehamilan pada wanita muda dengan peningkatan risiko masalah kesehatan dan kematian akibat melahirkan anak usia dini. Adanya beragam jenis alat kontrasepsi dapat mencegah kehamilan yang tidak diinginkan, termasuk pada wanita yang menghadapi peningkatan risiko kehamilan. Penggunaan alat kontrasepsi juga mampu mengurangi risiko kehamilan yang tidak diinginkan dan memberikan perlindungan terhadap infeksi HIV/AIDS terutama pada metode kondom. ${ }^{3}$ Penggunaan alat kontrasepsi ada 2 jenis yaitu kontrasepsi modern dan kontrasepsi tradisional. Kontrasepsi modern terdiri atas pil yang mengandung hormon progesterone dan estrogen (pil KB), implant, suntik hormon progesterone, IUD, kondom, sterilisasi pria (vasectomy), dan sterilisasi wanita (tubectomy). Sedangkan untuk kontrasepsi tradisional terdiri atas metode kalender, dan senggama terputus. Metode kontrasepsi modern mempunyai efektivitas mencegah kehamilan $\geq 93 \%$ sedangkan metode kontrasepsi tradisional mempunyai efektivitas mencegah kehamilan $\geq$ $73 \% .^{1}$

\section{HASIL}

Tabel 1 menggambarkan bahwa sebagian besar usia ibu berada dalam kategori $>35$ tahun dengan jumlah anak $\leq 2$, status bekerja, tingkat
Penelitian tentang pemilihan metode kontrasepsi sudah banyak dilakukan. Faktor yang ditemukan berhubungan adalah faktor predisposisi berupa pengetahuan, sikap dan persepsi tentang nilai anak, dan faktor penguat berupa dukungan suami dan petugas kesehatan. ${ }^{4}$ Berdasarkan hal tersebut maka penelitian ini ditujukan untuk mengetahui hubungan antara karakteristik, tingkat pengetahuan, dan sikap PUS dengan pemilihan alat kontrasepsi.

\section{BAHAN DAN METODE}

Penelitian ini merupakan penelitian analitik cross sectional dengan subjek penelitian adalah PUS yang berdomisili di wilayah Kecamatan Sidemen, Kabupaten Karangasem pada bulan Maret hingga April Tahun 2018. PUS yang terlibat dalam penelitian ini sebanyak 91 orang yang dipilih dengan metode simple random. Daftar PUS didapatkan dari catatan kantor desa. Data yang dikumpulkan adalah metode kontrasepsi, karakteristik PUS yang terdiri dari umur, tingkat pendidikan, tingkat penghasilan, tingkat pengetahuan dan sikap. Semua data dikumpulkan dengan metode wawancara yang dilakukan di masing-masing rumah responden. Responden yang tidak ditemukan pada saat kunjungan dikeluarkan dari populasi sampel. Data penelitian dianalisis secara deskriptif dan analitik. Analisis deskriptif dilakukan untuk mengetahui distribusi frekuensi dari masing-masing variabel. Sedangkan analitik dilakukan dengan uji Chi square untuk mengetahui faktor yang berhubungan dengan pemilihan alat kontrasepsi. Penelitian ini sudah mendapatkan ijin dari Komisi Etik Penelitian Fakultas Kedokteran Universitas Udayana dengan kelayakan Etik Nomor: 208/UN.14.2/KEP/2018 tertanggal 31 Januari 2018.

pendidikan ibu rendah, tingkat penghasilan rendah, sikap baik dan tingkat pengetahuan buruk. 
Tabel 1. Distribusi frekuensi karakteristik demografis pasangan usia subur

\begin{tabular}{llcc}
\hline Variabel & \multicolumn{1}{c}{ Kategori } & Frekuensi & Persentase (\%) \\
& & & \\
\hline Usia ibu & $20-35$ tahun & 44 & 48,4 \\
Jumlah anak ibu yang hidup & $>35$ tahun & 47 & 51,6 \\
& $\leq 2$ anak & 66 & 72,5 \\
Pekerjaan ibu & $>2$ anak & 25 & 27,5 \\
& Bekerja & 63 & 69,2 \\
Pendidikan ibu & Tidak bekerja & 28 & 30,8 \\
& Tinggi & 3 & 3,3 \\
\multirow{2}{*}{ Tingkat penghasilan } & Sedang & 31 & 34,1 \\
& Rendah & 57 & 62,6 \\
Sikap ibu terhadap KB & Tinggi & 40 & 44,0 \\
\multirow{2}{*}{ Tingkat pengetahuan ibu tentang KB } & 56 & 55,0 \\
& Rendah & 76 & 88,0 \\
& Baik & 15 & 12,0 \\
& Buruk & 28 & 30,7 \\
& Baik & 63 & 69,3 \\
\hline
\end{tabular}

Tabel 2 menggambarkan sebesar 45,1\% PUS memilih alat kontrasepsi MKJ

Tabel 2. Distribusi frekuensi pemilihan alat kontrasepsi

\begin{tabular}{lcc}
\hline \multicolumn{1}{c}{ Pemilihan Alat Kontrasepsi } & Jumlah & Persentase \\
\hline & $(\mathrm{n})$ & $(\%)$ \\
MKJP & 41 & 45,1 \\
Non MKJP & 50 & 54,9 \\
\hline
\end{tabular}

Pada tabel 3 dijumpai tingkat pengetahuan berhubungan dengan pemilihan alat kontraspsi sedangkan variabel lainnya ditemukan tidak berhubungan. 
Tabel 3. Analisis bivariat faktor predisposisi pemilihan alat kontrasepsi

\begin{tabular}{|c|c|c|c|c|c|}
\hline Variabel & Kategori & $\begin{array}{c}\text { Non } \\
\text { MKJP }\end{array}$ & MKJP & $\mathrm{X}^{2}$ & $\begin{array}{c}\mathrm{P} \\
\text { Value }\end{array}$ \\
\hline \multirow[t]{2}{*}{ Usia ibu } & 20-35 tahun & $\begin{array}{c}18 \\
(40,9 \%)\end{array}$ & $\begin{array}{c}26 \\
(59,1 \%)\end{array}$ & 0,096 & 0,442 \\
\hline & $>35$ tahun & $\begin{array}{c}23 \\
(48,9 \%)\end{array}$ & $\begin{array}{c}24 \\
(51,1 \%)\end{array}$ & & \\
\hline \multirow[t]{2}{*}{ Paritas } & $\leq 2$ anak & $\begin{array}{c}35 \\
(70,0 \%)\end{array}$ & $\begin{array}{c}31 \\
(75,6 \%)\end{array}$ & 0,061 & 0,527 \\
\hline & $>2$ anak & $\begin{array}{c}15 \\
(30,0 \%)\end{array}$ & $\begin{array}{c}10 \\
(24,4 \%)\end{array}$ & & \\
\hline \multirow[t]{2}{*}{ Pekerjaan ibu } & Bekerja & $\begin{array}{c}36 \\
(72,0 \%)\end{array}$ & $\begin{array}{c}27 \\
(65,9 \%)\end{array}$ & 0,66 & 0,649 \\
\hline & Tidak bekerja & $\begin{array}{c}14 \\
(28,0 \%)\end{array}$ & $\begin{array}{c}14 \\
(28,0 \%)\end{array}$ & & \\
\hline \multirow[t]{3}{*}{ Pendidikan ibu } & Tinggi & $\begin{array}{c}1 \\
(33,3 \%)\end{array}$ & $\begin{array}{c}2 \\
(66,7 \%)\end{array}$ & 0,012 & 0,027 \\
\hline & Sedang & $\begin{array}{c}20 \\
(64,5 \%)\end{array}$ & $\begin{array}{c}11 \\
(35,5 \%)\end{array}$ & & \\
\hline & Rendah & $\begin{array}{c}20 \\
(35,1 \%)\end{array}$ & $\begin{array}{c}37 \\
(64,9 \%)\end{array}$ & & \\
\hline \multirow[t]{2}{*}{ Tingkat penghasilan } & Tinggi & $\begin{array}{c}19 \\
(38,0 \%)\end{array}$ & $\begin{array}{c}21 \\
(51,2 \%)\end{array}$ & 0,132 & 0,206 \\
\hline & Rendah & $\begin{array}{c}31 \\
(62,0 \%)\end{array}$ & $\begin{array}{c}20 \\
(48,8 \%)\end{array}$ & & \\
\hline \multirow[t]{2}{*}{ Sikap ibu terhadap KB } & Baik & $\begin{array}{c}41 \\
(98,0 \%)\end{array}$ & $\begin{array}{c}39 \\
(87,6 \%)\end{array}$ & 0,163 & 0,627 \\
\hline & Buruk & $\begin{array}{c}18 \\
(32,0 \%)\end{array}$ & $\begin{array}{c}12 \\
(24,0 \%)\end{array}$ & & \\
\hline \multirow[t]{2}{*}{$\begin{array}{l}\text { Tingkat pengetahuan ibu } \\
\text { tentang KB }\end{array}$} & Baik & $\begin{array}{c}38 \\
(55,1 \%)\end{array}$ & $\begin{array}{c}31 \\
(44,9 \%)\end{array}$ & 0,161 & 0,01 \\
\hline & Buruk & $\begin{array}{c}3 \\
(13,6 \%)\end{array}$ & $\begin{array}{c}19 \\
(86,4 \%)\end{array}$ & & \\
\hline
\end{tabular}

\section{PEMBAHASAN}

Dalam penelitian ini didapatkan bahwa sebesar 45,1\% PUS memilih alat kontrasepsi MKJP, sedangkan penggunaan alat kontrasepsi non MKJP sebesar 54,9\%. Hasil ini lebih rendah jika dibandingkan dengan angka nasional pengguna alat kontrasepsi yaitu peserta KB yang menggunakan non-MKJP yaitu sebesar $81,33 \%$, sedangkan peserta $\mathrm{KB}$ baru yang menggunakan MKJP hanya sebesar $18,17 \% .{ }^{5}$ Penelitian yang dilakukan di Jawa Timur juga mendapatkan bahwa jumlah pengguna alat kontrasepsi Non MKJP (72\%) lebih banyak dibandingkan dengan pengguna MKJP (28\%). ${ }^{6}$
Hasil penelitian menunjukkan bahwa dari variabel yang diteliti hanya terdapat satu variabel yang berhubungan dengan pemilihan alat kontrasepsi yaitu tingkat pengetahuan PUS dimana ibu yang mempunyai pengetahuan baik lebih memilih menggunakan alat kontrasepsi non MKJP dibanding dengan alat kontrasepsi MKJP. Hasil ini berbeda dengan hasil penelitian yang dilakukan di wilayah kerja puskesmas Pundata Baji yang mendapatkan bahwa PUS yang memiliki tingkat pengetahuan rendah cenderung lebih memilih alat kontrasepsi non MKJP. Pengetahuan merupakan domain yang penting dalam membentuk tindakan seseorang dan merupakan faktor predisposisi terbentuknya 
perilaku termasuk perilaku penggunaan MKJP. ${ }^{7}$ Dalam penelitian ini ibu yang mempunyai pengetahuan baik yaitu sebesar $55,1 \%$ memilih menggunakan alat kontrasepsi

non MKJP. Berdasarkan hasil penelitian yang dilakukan di Jawa Timur ditemukan bahwa alasan utama ibu memilih alat kontrasepsi non MKJP adalah harga alat kontrasepsi non MKJP lebih murah dibandingkan dengan dengan alat kontrasepsi MKJP. Selain itu biaya pemasangan alat kontrasepsi juga berbeda antara non MKJP dan MKJP, pemasangan alat non MKJP lebih murah dibandingkan dengan biaya pemasangan alat kontrasepsi MKJP. ${ }^{8}$ Menurut hasil penelitian yang dilakukan di wilayah kerja puskesmas Kecamatan Samarang Kabupaten Garut mendapatkan bahwa pengetahuan masyarakat dapat mempengaruhi penerimaan program KB di masyarakat. Pengetahuan tentang program KB termasuk macam-macam jenis kontrasepsi akan meningkatkan keikutsertaan masyarakat dalam program KB. ${ }^{9}$ Pengetahuan PUS yang tinggi dapat menggambarkan wawasan yang lebih luas sehingga memudahkan dalam menerima inovasi baru dan pengambilan keputusan yang sesuai termasuk dalam memutuskan memilih jenis alat kontrasepsi yang diinginkan. ${ }^{10}$

\section{SIMPULAN}

Sebagian besar usia ibu berada dalam kategori $>35$ tahun dengan jumlah anak $\leq 2$, status bekerja, tingkat pendidikan ibu rendah, tingkat penghasilan rendah, tingkat pengetahuan buruk, dan sikap baik. Sebesar 45,1 \% PUS memilih alat kontrasepsi MKJP. Tingkat pengetahuan berhubungan dengan pemilihan alat kontraspsi sedangkan variabel lainnya ditemukan tidak berhubungan. Sehingga perlu disosialisasikan tentang kelebihan dan kekurangan masing-masing metode kontrasepsi untuk memastikan pemilihan kontrasepsi yang tepat bagi ibu pasangan usia subur.

\section{DAFTAR PUSTAKA}

1. WHO. Family planning/contraceptive. 2018. Tersedia di :http://www.who.int/news-room/factsheets/detail/family-planningcontraception.Diakses: 24 Oktober 2018.

2. United Nations. Trends in contraceptive use worldwide. 2015. Tersedia di : http://www.un.org/en/development/des a/population/publications/pdf/family/tr endsContraceptiveUse2015Report.pdf. Diakses: 9 Nopember 2018.

3. WHO. Contraception : Issues in Adolescent Health and Development. Department of Child and Adolescent Health and Development World Health Organization, Geneva. 2004

4. Wijayanti RU \& Novianti. Penggunaan $\mathrm{kb}$ metode kontrasepsi jangka panjang (mkjp) di wilayah kerja puskesmas kecamatan sawah besar jakarta pusat. Jurnal Ilmiah Widya. 2017; 4(1): $243-$ 248.

5. Djauharoh A. Hadie, Martha Irene Kartasurya, dan Cahy Tri Purnami.Beberapa faktor yang berhubungan dengan penggunaan metoda kontrasepsi jangka panjang (studi pada akseptor KB di kabupaten Sidoarjo Provinsi Jawa Timur). Jurnal Manajemen Kesehatan Indonesia. 2015; 03(01): 27-33.

6. Sriayu Bintari S, Andi Zulkifli A \& Ansariadi. Faktor yang berhubungan dengan pemilihan alat kontrasepsi di Wilayah Kerja Puskesmas Pundata Baji. Skripsi. Fakultas Kesehatan Masyarakat Universitas Hasanuddin. 2015.

7. Rendys Septalia \& Nunik Puspitasari. Faktor yang memengaruhi pemilihan metode kontrasepsi. Jurnal biometrika dan kependudukan. 2016; 5(2):

91-98. 
8. Kusumastuti, Martha Irene Kartasurya, \& Cahya Tri Purnami. Analisis faktorfaktor yang berhubungan dengan perilaku pelayanan kontrasepsi oleh bidan di kabupaten kebumen. Jurnal keperawatan Soedirman. 2013; 8(1): 22-31. yang mempengaruhi pemilihan metode kontrasepsi jangka panjang (MKIP) pada wanita pasangan usia subur (PUS) di Kabupaten Kendal Tahun 2013. Jurnal Promosi Kesehatan Indonesia. 2016; 11(2): 32-46.

9. Sri Setiasih, Bagus Widjanarko dan Tinuk Istiarti. Analisis Faktor-faktor 